\title{
DNA from Leaf or Stem: A Comparative Work on Dianthus L. for DNA Barcoding Analysis with Four Commercial Extraction Kits
}

\section{Yaprak ya da Gövde DNA'sı: Dianthus L. DNA Barkod Analizi için Dört Ticari Ekstraksiyon Kitinin Karşılaştırması}

\author{
Zübeyde Uğurlu Aydın ${ }^{1 *}$, Mustafa K. Şenova ${ }^{1}$, Marcus A. Koch $^{2}{ }^{\oplus}$, Ali A. Dönmez ${ }^{1 \oplus}$ \\ ${ }^{1}$ Molecular Plant Systematic Laboratory (MOBIS), Department of Biology, Faculty of Science, Hacettepe University, Ankara 06800, Turkey. \\ ${ }^{2}$ Center for Organismal Studies (COS) Heidelberg/Botanic Garden and Herbarium Heidelberg (HEID), University of Heidelberg, Im Neuenheimer \\ Feld 345, D-69120 Heidelberg, Germany.
}

\section{A B STRACT}

— our widely used DNA extraction kits, GeneAll GenEx ${ }^{\top M}$ Plant kit, GeneMATRIX Plant \& Fungi DNA Purification kit, DNeasy - Plant kit and E.Z.N.A. Plant DNA kit, were compared using leaf and stem tissues of Dianthus specimens to isolate high yield and quality genomic DNA for DNA barcoding. Traditionally, leaves are used as a main source of genomic DNA but extracting DNA from Dianthus leaves might be more difficult because of sclerenchymatic tissues. Genomic DNA was extracted based on manufacturers' protocols and amplified for seven barcode regions by PCR. DNA concentrations were measured using fluorometer and the quality of DNA and PCR products were showed on agarose gel. Amplification results were evaluated in terms of Polymerase Chain Reaction (PCR) success for DNA barcoding research. Additionally, comparisons between the efficiency of commercial kits were discussed in terms of cost, labor and time-consuming. Results presented here, DNA extraction carried out from both stem and leaves of Dianthus specimens successfully. Although, all kits performed well for PCR amplification, GeneMATRIX was found the best efficient kit for isolating high quality DNA of Dianthus specimens used in the study for leaf and stem tissues.

\section{Key Words}

DNA isolation, PCR success.

\section{öz}

eneAll GenEx ${ }^{\text {TM }}$ Plant kiti, GeneMATRIX Plant \& Fungi DNA Purification kiti, DNeasy Plant kiti ve E.Z.N.A. Plant DNA kiti $\checkmark$ yaprak ve gövde dokusu DNA barkodlama çalışmaları için kaliteli ve yüksek genomik DNA elde etmek amacıyla test edilmiştir. Geleneksel olarak yaprak dokusu genomik DNA kaynağı olarak kullanılmaktadır fakat Dianthus taksonları yaprak sklerankima dokusu nedeniyle bu bakımdan sorunludur. Genomik DNA, üretici firmaların sağladığı protokole göre elde edilmiştir ve yedi barkod bölgesi PCR yöntemiyle çoğaltılmıştır. İzole edilen DNA konsantrasyonu florometrik yöntemle ölçülmüş, PCR ürünleri agaroz jelde görüntülenmiştir. Sonuçlar, DNA barkodlama çalışmalarında kullanılabilecek PCR başarısı bakımından değerlendirilmiştir. Ayrıca, kullanılan ekstraksiyon kitleri iş gücü, fiyat ve zaman bakımından değerlendirilmiştir. Sonuçlarımıza göre, yaprak ve gövde dokusundan genomik DNA ekstraksiyonu başarıyla gerçekleştirilmiştir. Tüm ekstraksiyon kitleri PCR amplifikasyonu bakımından başarılı olmasına rağmen en yüksek verim GeneMATRıX kiti kullanılarak elde edilmiştir.

\section{Anahtar Kelimeler}

DNA izolasyonu, PCR başarısı. 


\section{INTRODUCTION}

Isolation of genomic DNA is basic and first step of any genetic research. However, genomic DNA extraction with high quality and large quantity is often the limiting factor for plant molecular analysis [1]. Cell wall, specific pigments and secondary compounds of plants make DNA isolation more difficult compared to animal tissues [2-3] and inhibit further downstream applications [4]. Isolation of high quality DNA from plant is also time-consuming and expensive [5-6]. To overcome all, several attempts [7-13] has been made to obtain suitable genomic DNA from various plant tissues using silicaspin column methods or hexadecyltrimethylammonium bromide (CTAB) based method, described by Doyle and Doyle [14]. Unlike commercial kits based on silica-spin column method, traditional CTAB protocol include various time-consuming steps and are comparatively laborious. Indeed, rapid isolation method with high quality DNA is increasing need particularly for systematic research of genetic diversity [15]. DNA barcoding is a tool for fast and accurate identification of organisms. The main goal of plant DNA barcoding is to use short and standardized DNA fragments promoted by CBOL (Consortium for the Barcode of Life) for identification and particularly, plant DNA barcoding researches depend on high yields of pure genomic DNA [16]. An efficiency of different extraction methods have been also tested several times using leaves for different purposes [e.g., $13,17-21]$ and some of them were specifically focused on suitable DNA isolation methods for DNA barcoding research [e.g., 16, 22].

Dianthus is native to Asia and Europe [23] and a few species are known from Africa and America [24]. It consists of 600 species, among which 78-84 species are recorded for flora of Turkey [25-27]. An ongoing research on barcoding of Dianthus taxa in Turkey and adjacent regions face to some challenges and gives some insights for methodology. DNA isolation from leaves of Dianthus have some difficulties because of much sclerenchymatous and less parenchymatic tissues. Additionally, the leaves becoming dry in a short time at field conditions. Unlikely, stem can long survive in green and the tissue is softer than leaf. We suspected that stem tissue is a good option for DNA extraction instead of leaves to Dianthus samples. Despite the variety of DNA isolation protocols, no research has been presented so far comparing their efficiency for leaves or stem of Dianthus. However increasing plant barcoding researches, only Heise et al. [28] were tested one Dianthus species based on three barcode markers for ecological purposes.

The aim of this work is to evaluate different commercial kits for extraction of high yield DNA using leaves and stems of Dianthus specimens and to establish efficient method for DNA barcoding. In order to detect suitability of genomic DNA for barcoding, PCR was applied seven barcode regions, recommended by CBOL [29].

\section{MATERIALS and METHODS}

Stem and leaf tissues used for this study were collected from two Dianthus taxa during field trips (Table 1). All collected samples kept on silica gel in the field and deposited at -20 refrigerator until DNA extraction. Genomic DNA was extracted by using the four commercial kits (Table 2) according to manufacturers' instructions. Mechanical cell lysis was applied at $150 \mathrm{~Hz}$ for $30 \mathrm{~s}$ by MagNA Lyser (Hoffmann-La Roche Ltd) to $0.8 \mathrm{~g}$ each of leaf and stem tissues (Table 2). For leaf samples, this step was repeated at least twice. Before the incubation step, samples were treated with different amount of RNase A based on instructions. Incubation of all samples then were standardized at $60^{\circ} \mathrm{C}$ for $1 \mathrm{~h}$. All extracted DNA was eluted in $50 \mu \mathrm{l}$ of appropriate elution buffer supplied by manufacturers. The DNA yield (ng) of extracted genomic DNA were measured by Qubit 3.0 fluorometer using High Sensitivity Kit (Thermofischer Scientific, Massachusetts, United States of America). The integrity of genomic DNA was determined by separating approximately $500 \mathrm{ng}$ of DNA on a \%1 agarose gel (w/v) containing $8 \mu$ l of DNA stain (GreenSafe Direct Load, NZYTech), run in $1 \times$ tris-borate-EDTA buffer at $50 \mathrm{~V}$ for $1 \mathrm{~h}$.

Table 1. Details of Dianthus specimens.

\begin{tabular}{cc}
\hline Taxa & Voucher \\
\hline Dianthus anatolicus Boiss. & Turkey: Afyon, Çay, $1306 \mathrm{~m}, 42^{\circ} 51^{\prime} 3.9^{\prime \prime} \mathrm{N}, 31^{\circ} 04^{\prime} 27^{\prime \prime E}, 20.6 .2018$, A.A. Dönmez \\
$20098-$ Z. Uğurlu
\end{tabular}


Table 2. Details of commercial kits and starting amount used in this study.

\begin{tabular}{|c|c|c|c|}
\hline Full name of the kit & $\begin{array}{l}\text { Manufacturer } \\
\text { details }\end{array}$ & Starting amount (g) & Supplied material by users \\
\hline GeneAll GenEx ${ }^{\mathrm{TM}}$ Plant Kit & $\begin{array}{c}\text { GeneAll Biotechnology } \\
\text { Co., Ltd. Korea }\end{array}$ & 0.8 & - \\
\hline $\begin{array}{c}\text { GeneMATRIX Plant \& Fungi } \\
\text { DNA Purification Kit }\end{array}$ & EURx Ltd., Poland & 0.8 & - \\
\hline DNeasy Plant kit & $\begin{array}{c}\text { QIAGEN, California, } \\
\text { USA }\end{array}$ & 0.8 & - \\
\hline E.Z.N.A. Plant DNA Kit & $\begin{array}{l}\text { Omega Bio-tek, Inc., } \\
\text { Georgia, USA }\end{array}$ & 0.8 & $\beta$-mercaptoethanol \\
\hline
\end{tabular}

Primers and PCR conditions were followed by CBOL [29]. To run PCR reaction, total volume of $20 \mu$, containing 15-30 ng of genomic DNA, 10 pmol of Forward and Reverse primer (Macrogen, Netherlands), and 1X HS Prime Taq Premix (Genetbio, Korea). PCR was performed using Gradient Master Cycler (Eppendorf, Germany) at different days. The amplification products were detected by electrophoresis in \%1 agarose gel (w/v) containing $4 \mu \mathrm{l}$ of DNA stain (GreenSafe Direct Load, NZYTech), run in $1 \times$ tris-borate-EDTA buffer at $100 \mathrm{~V}$ for $30 \mathrm{~min}$.

\section{RESULTS}

According to florometric analysis, the yields of genomic DNA from leaf ranged between 38 and $740 \mathrm{ng}$ while from stem ranged between 15 and 100 ng (Table 2). Among commercial kits, GeneMATRIX and E.Z.N.A. were more efficient for leaf and stem for two specimens of Dianthus. Fluorometric and electrophoretic analysis showed that DNeasy is not successful for extracting genomic DNA of Dianthus tissues. The highest DNA and brightest bands from leaf and stem obtained using by GeneMATRIX (Table 3, Figure 1).

However, efficiency of GeneAll and DNeasy were very low, all kits enable to obtain enough DNA for subsequent analysis (Figures 1-3). Extracted DNA from tissues allow to amplify successfully for barcoding regions. All target bands were separated on the gel at their expected size, between 400-700 bp. Unlike the other commercial kits, amplification of rpoB, atpF-H and matK obtained by DNeasy and E.Z.N.A were not visible and distinct well. These findings showed that, PCR of barcoding regions were supported DNA yield and purity of extracting DNA

Table 3. Concentrations of isolated genomic DNA from Dianthus specimens.

\begin{tabular}{|c|c|c|c|}
\hline Taxa & Tissue & Commercial kit & Concentration $(\mathrm{ng} / \mu \mathrm{l})$ \\
\hline D. anatolicus & $\begin{array}{l}\text { Leaf } \\
\text { Stem }\end{array}$ & GeneAll GenEx ${ }^{\top M}$ & $\begin{array}{l}6.76 \\
6.76\end{array}$ \\
\hline D. anatolicus & $\begin{array}{l}\text { Leaf } \\
\text { Stem }\end{array}$ & GeneMATRIX & $\begin{array}{c}14.8 \\
22\end{array}$ \\
\hline D. anatolicus & $\begin{array}{l}\text { Leaf } \\
\text { Stem }\end{array}$ & DNeasy & $\begin{array}{c}1.1 \\
0.65\end{array}$ \\
\hline D. anatolicus & $\begin{array}{l}\text { Leaf } \\
\text { Stem }\end{array}$ & E.Z.N.A. & $\begin{array}{l}11.8 \\
12.8\end{array}$ \\
\hline D. cruentus & $\begin{array}{l}\text { Leaf } \\
\text { Stem }\end{array}$ & GeneAll GenEx ${ }^{\top \mathrm{M}}$ & $\begin{array}{l}14.8 \\
3.87\end{array}$ \\
\hline D. cruentus & $\begin{array}{l}\text { Leaf } \\
\text { Stem }\end{array}$ & GeneMATRIX & $\begin{array}{l}22.4 \\
6.96\end{array}$ \\
\hline D. cruentus & $\begin{array}{l}\text { Leaf } \\
\text { Stem }\end{array}$ & DNeasy & $\begin{array}{c}0.76 \\
0.3\end{array}$ \\
\hline D. cruentus & $\begin{array}{l}\text { Leaf } \\
\text { Stem }\end{array}$ & E.Z.N.A. & $\begin{array}{l}10.9 \\
6.48\end{array}$ \\
\hline
\end{tabular}


with GeneMATRIX. However, DNA amount was yielded higher using E.Z.N.A kit, PCR bands were not distinct compare with GeneMATRIX or GeneAll. It would be the reason that isolated DNA have low purity level for PCR amplification. Most of samples showed clean bands but interestingly significant smear were visualized on DNA isolated by GeneAll and GeneMatrix. The reason would be degradation of samples.

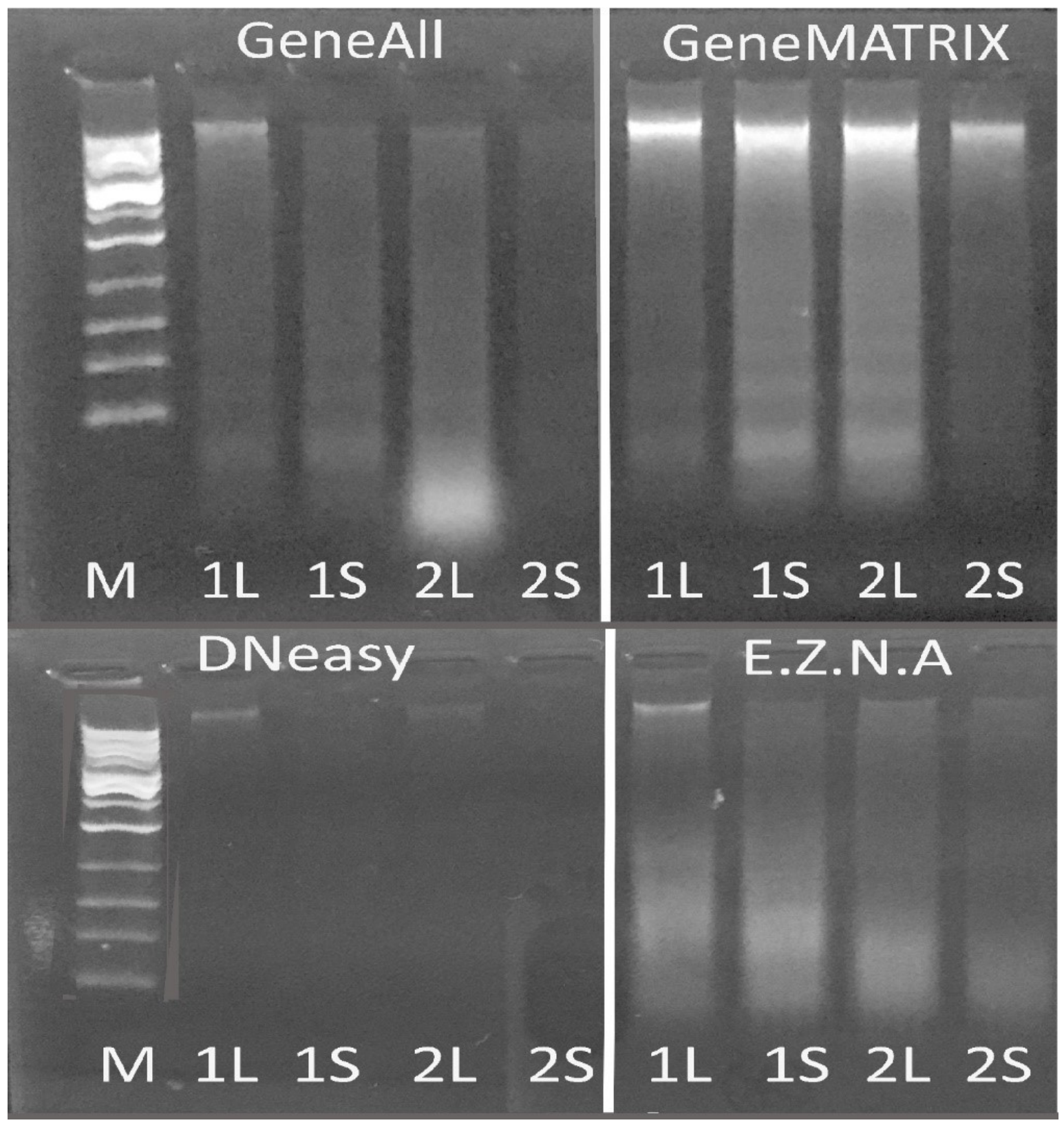

Figure 1. Genomic DNA isolated from Dianthus specimens. L: leaf tissue, S: stem tissue, M: 1 kb DNA ladder. Numbers are the same with Table 1. 


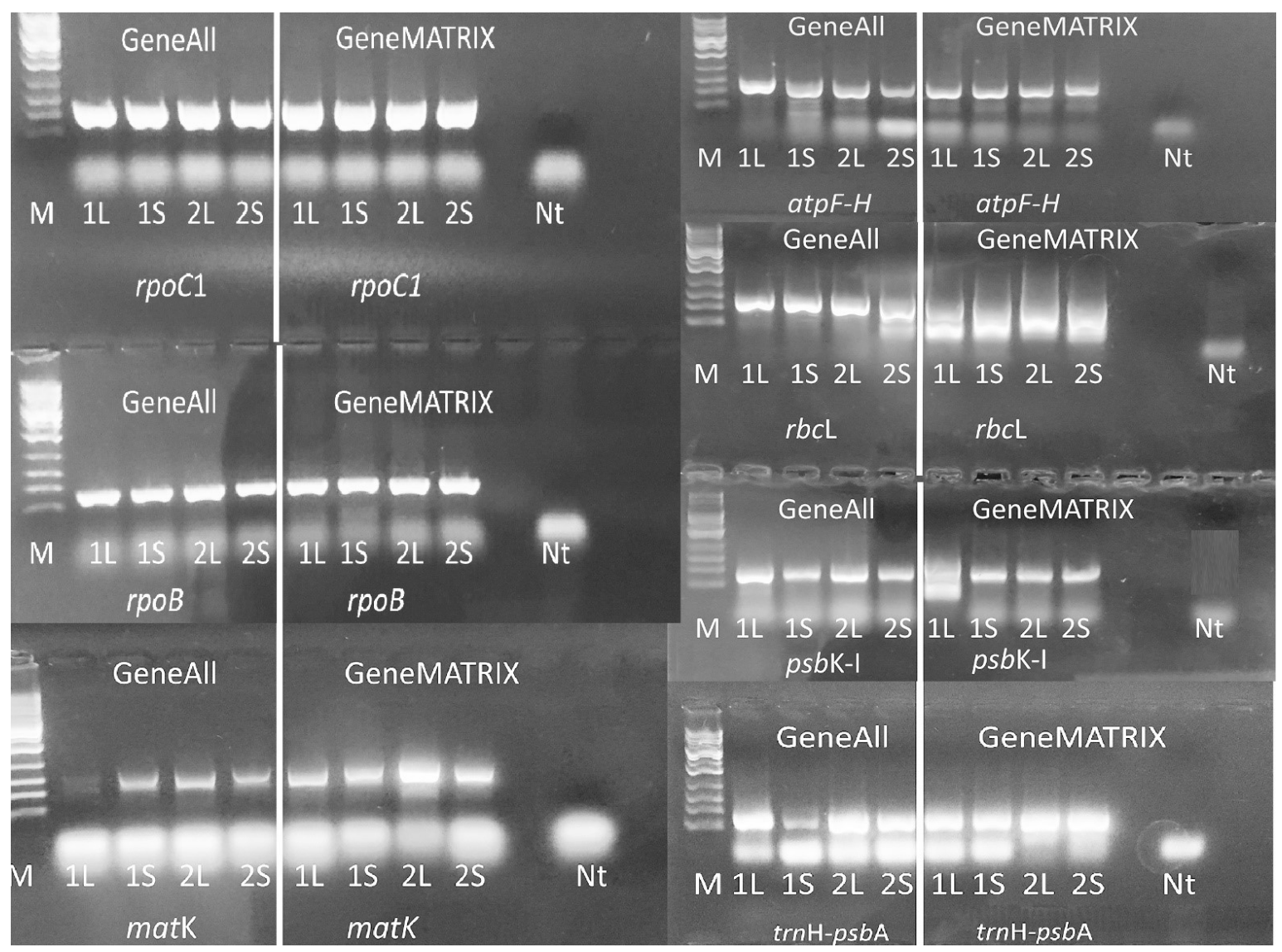

Figure 2. Amplification of barcoding regions visualized by gel electrophoresis. L: leaf tissue, S: stem tissue, M: 1 kb DNA ladder, Nt: Negative template.

\section{DISCUSSION}

Some problems can arise when leaves are counted as the only source of genomic DNA. This kind of cases, researchers have to find an alternative source, apart from leaves, to achieve first step of molecular studies. For this purpose, several isolation method have been developed depend on plant materials [e.g., 10,30,31]. Indeed, Yin et al. [9], obtained higher yields from seeds, stems and root tissues than from leaves.

In this study, except DNeasy, leaves and stem yielded high genomic DNA but the amount is varied depend on kits and target tissue. This allows us stem is an option as good as leaves for genomic DNA but also it has advantages in terms of less laborious compare with stuff leaves.

Numerous studies have been documented to detect standards of an ideal DNA extraction method. High DNA yield, low price, less laborious are accepted an important part of these standards [16]. Commercial kits tested here have comparable price and GeneAll and Gene Matrix are the minimum prices. Time is another important parameter to test efficiency of the kits. All procedure were taken reasonable time and almost two hours should be spent for all these four kits. However, E.Z.N.A. needs the material supplied by users and it gets extra cost and more laborious. According to results, GeneAll and Gene Matrix meet these standards successfully.

Plant DNA barcoding methods allows species identification based on DNA sequences in a much shorter time frame. The method is developed especially when morphology based taxonomy is insufficient to resolve taxonomic problems. PCR success is one of important level to obtain robust sequence for barcoding research [16]. In this study, PCR amplification for all regions were successful in producing bands for all samples. Finally, with these kits, it is possible to obtain sufficient genomic DNA from leaves and stem of Dianthus specimens for DNA barcoding. This finding is also important when leaves are in poor condition or they are absent in the plant. 


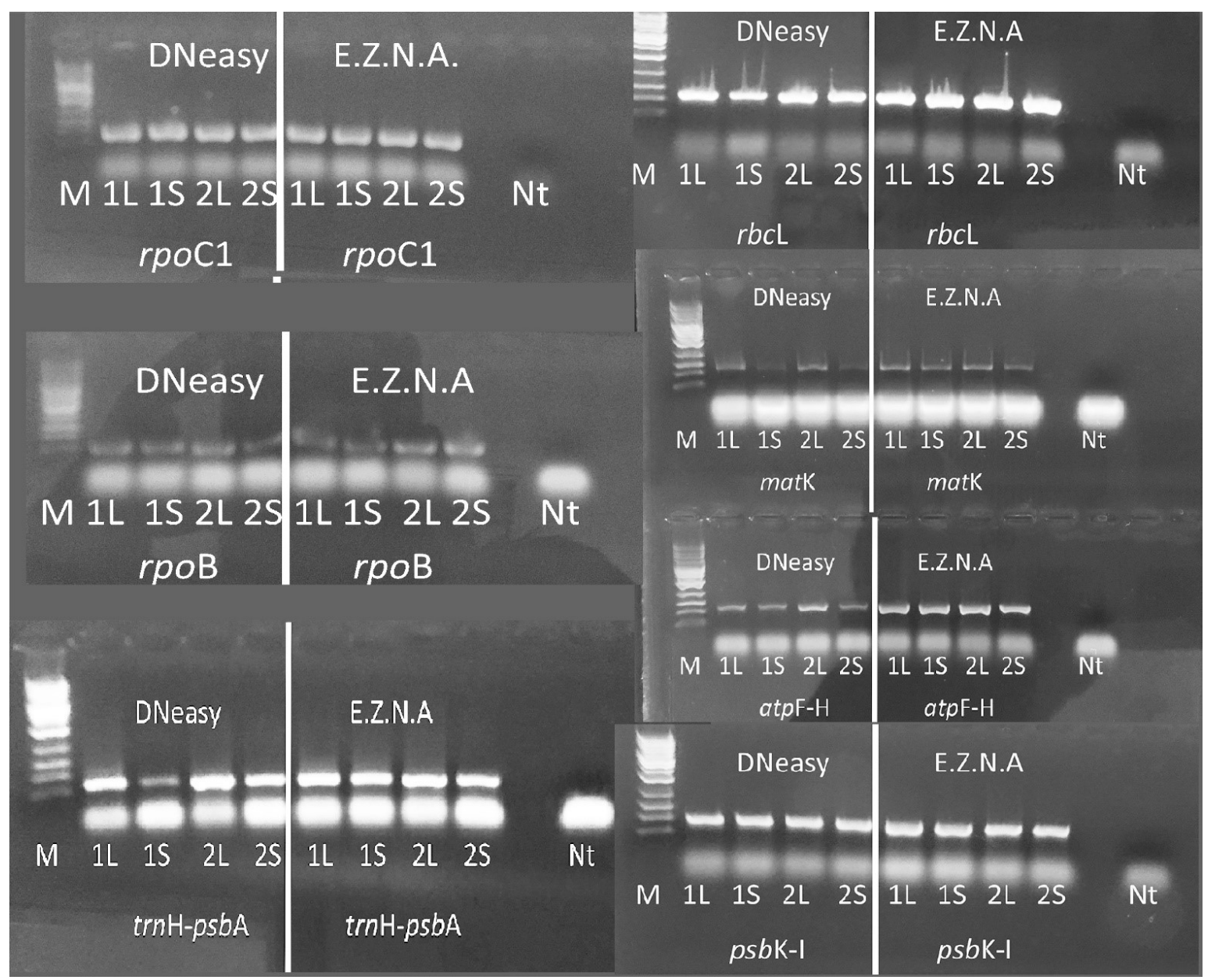

Figure 3. Amplification barcoding regions visualized by gel electrophoresis. L: leaf tissue, S: stem tissue, M: 1 kb DNA ladder, Nt: Negative template.

As a result, the highest DNA amount was yielded from E.Z.N.A kit with GeneMatrix kits using both $0.8 \mathrm{~g}$ leaf and stem tissue. We presented here stem would be an alternative sampling for researchers interested in carrying on barcoding analysis of Dianthus. Also the GeneMatrix and GeneAll kit are more suitable for DNA barcoding according to PCR success. In terms of DNA extraction and DNA barcoding, GeneMatrix kit allows highest quantity of DNA and also succeed amplification of all DNA barcode regions.

Acknowledgments - The study was conducted as a part of the project titled "DNA Barcoding Research on some Dianthus L. (Caryophyllaceae) in Turkey" supported by Hacettepe University (FBA-2018-16187).

\section{References}

1. Z. Xin, J. Chen, A high throughput DNA extraction method with high yield and quality, Plant Methods, 8 (2012) 26.

2. M.P. Griffith, M. Porter, Back to the basics: A simple method of DNA extraction for mucilaginous cacti, Bradleya, 21 (2003) 26-28.

3. J.F. Manen, O. Sinitsyna, L. Aeschbach, A.V. Marlov, A fully automatable enzymatic method for DNA extraction from plant tissues, BMC Plant Biol. Rep., 5 (2005) 23.

4. S. Bashalkhanov, O.P. Rajora, Protocol: A high-throughput DNA extraction system suitable for conifers, Plant Methods, 4 (2008) 20.

5. J. Steenkamp, I. Wild, A. Lourens, P. Van Helden, Improved method for DNA extraction from Vitis vinifera, Am. J. Enol. Vit., 45 (1994) 102-106.

6. S.M. Aljanabi, I. Martinez, Universal and rapid salt-extraction of high quality genomic DNA for PCR based techniques, Nucleic Acids Res., 25 (1997) 4692-4693.

7. X. Xu, S. Kawasaki, T. Fujimura, C. Wang, A protocol for high throughput extraction of DNA from rice leaves, Plant Mol. Biol. Rep., 23 (2005) 291-295.

8. E. Sözen, I. Poyraz, Rapid and high quality DNA isolation from Origanum onites for RAPD and ISSR analysis, Z Naturforsch C, 63c (2008) 595-598. 
9. D. Yin, H. Liu, X. Zhang, D. Cui, A protocol for extraction of high-quality RNA and DNA from peanut plant tissues, Mol. Biotechnol., 49 (2011) 187-191.

10. S.D. Fehlberg, J.M. Allen, K. Church, A novel method of genomic DNA extraction for Cactaceae, Appl. Plant Sci., 1 (2013).

11. Ç. Karaaslan, H. Akel, S. Ünlü, I. Perçin, Comparison of six commercial DNA extraction kits for DNA extraction from wheat, Hacettepe J. Biol. Chem., 42 (2014) 395-400.

12. i. Poyraz, An efficient DNA isolation method from Nigella sativa L. (Ranunculaceae) seeds for RAPD and ISSR analysis, Bilecik Şeyh Edebali Üniversitesi Fen Bilimleri Dergisi, 1 (2014) 2148-2330.

13. V.A. Scobeyeva, D.O. Omelchenko, L.M. Dyakov, A.S. Konovalov, A.S. Speranskaya, A.A. Krinitsina, Comparison of some plant DNA extraction methods, Russ. J. Genet., 5 (2018) 54.

14. J.J. Doyle, J.L. Doyle, A rapid DNA isolation procedure for small quantities of fresh leaf tissue, Phytochemical Bulletin, 19 (1987) 11-15.

15. D.E. Pearse, K.A. Crandall, F.S.T. Beyond, Analysis of population genetic data for conservation, Conserv. Genet. 5 (2004) 585-602.

16. J. Anerao, V. Jha, N. Desai, Optimization of DNA Extraction Methods from Garcinia species for ISSR-PCR, RAPD-PCR and DNA Barcoding, Asian J. Biotechnol., 9 (2017) 35-42.

17. M. Akkurt, Comparison between modified DNA extraction protocols and commercial isolation kits in grapevine (Vitis vinifera L.), Genet. Mol. Res., 11(3) (2012) 2343-2351.

18. B.D. Lade, A.S. Patil, H.M. Paikrao, Efficient genomic DNA extraction protocol from medicinal rich Passiflora foetida containing high level of polysaccharide and polyphenol, SpringerPlus, (2014) 457.

19. A. Abdel-Latif, G. Osman, Comparison of three genomic DNA extraction methods to obtain high DNA quality from maize, Plant Methods, 13 (2017) 1
20. C.S. Siegel, F.O. Stevenson, E.A. Zimmer, Evaluation and comparison of FTA card and CTAB DNA extraction methods for non-agricultural taxa, Appl. Plant Sci., 5 (2017) 1600109

21. B. Pipan, M. Zupančič, E. Blatnik, P. Dolničar, V. Meglič, Comparison of six genomic DNA extraction methods for molecular downstream applications of apple tree (Malus $X$ domestica), Cogent Food Agric., 4 (2018) 1540094.

22. G. Dittrich-Schröder, M.J. Wingfield, N.H. Klein, B. Slippers, DNA extraction techniques for DNA barcoding of minute gall-inhabiting wasps, Mol. Ecol. Resour., 12 (2012) 109-115.

23. G. Bacchetta, S. Brullo, M. Casti, G. Giusso del Galdo, Taxonomic revision of the Dianthus sylvestris group (Caryophyllaceae) in central southern Italy, Sicily and Sardinia, Nord. J. Bot., 28 (2010) 137-173

24. L. Dequan, N.J. Turland, Dianthus. In: Wu, Z.Y., Raven, P.H. \& Hong, D.Y. (Eds.) Flora of China. Vol. 6. Science Press, Beijing \& Missouri Botanical Garden Press, St. Louis, 2001, pp. 102107.

25. E. Hamzaoğlu, M. Koç, İ. Büyük, Two new spiny species of Dianthus (Caryophyllaceae) from Turkey, KSU J. Agric. Nat., 21 (2018) 545-554.

26. D. Oskay, Dianthus somanus (Caryophyllaceae), a new species from Turkey, Phytotaxa, 347 (2018) 263-271.

27. i.G. Deniz, C. Aykurt, I. Genç, A. Aksoy, A new species of Dianthus (Caryophyllaceae) from Antalya, South Anatolia, Turkey, PhytoKeys, 63 (2016) 1-12.

28. W. Heise, W. Babik, D. Kubisz, Ł. Kajtoch, DNA barcoding of xerothermic plants, Bot. J. Linn. Soc., 177 (2015) 576-592.

29. CBOL Plant Working Group, A DNA barcode for land plants, PNAS USA, 106 (2009), 12794-12797.

30. R.M.L. Novaes, J.G. Rodrigues, M.B. Lovato, An efficient protocol for tissue sampling and DNA isolation from the stem bark of Leguminosae trees, Genet. Mol. Res., 8 (2009) 86-96.

31. Z. Loo, S. Chandran, Extraction of genomic DNA from roots and leaves of Hylocereus undatus, Isr. J. Plant Sci., 60 (2012) 345-348 